

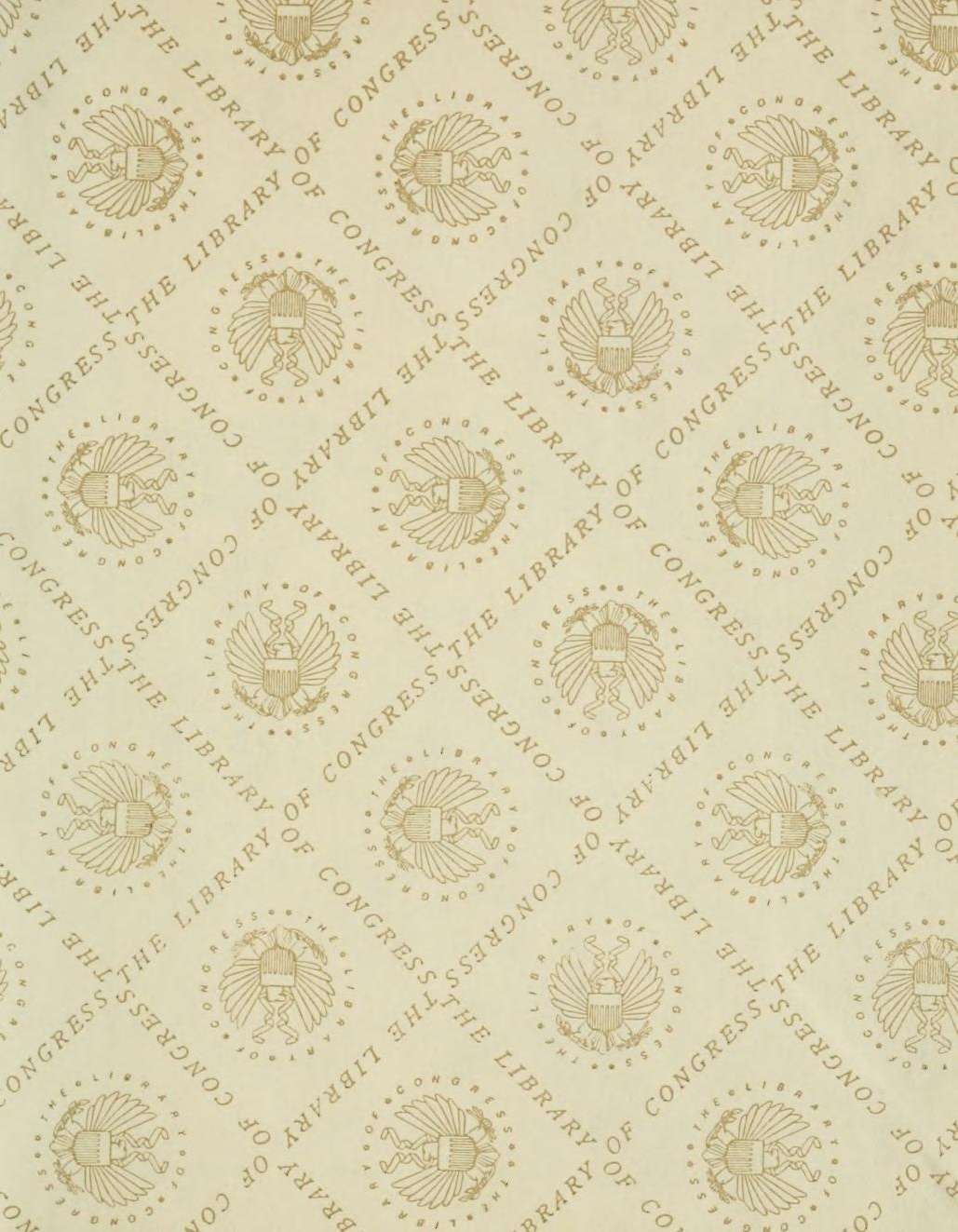





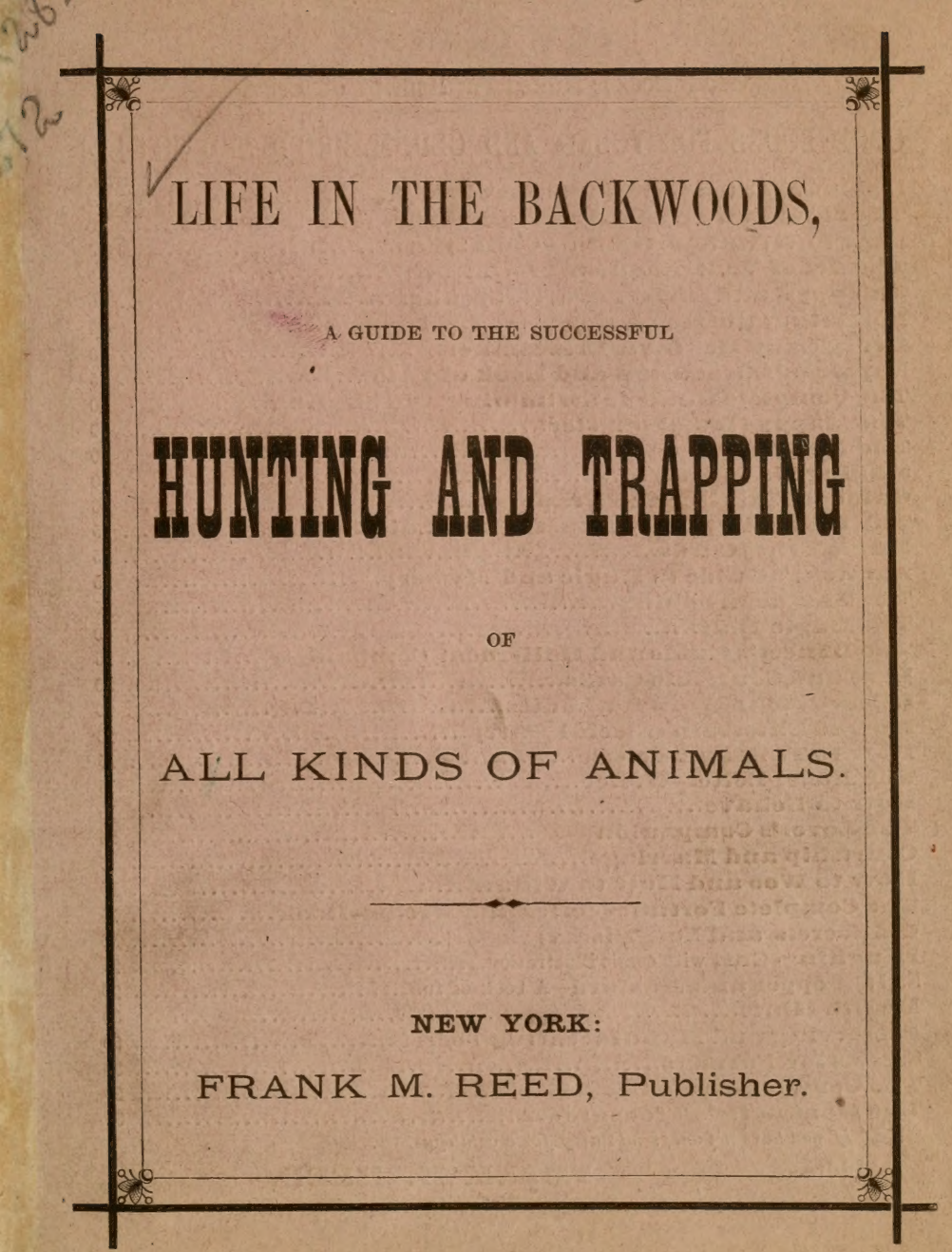




\section{GOOD BOOKS FOR YOUNG AND OLD, MARRIED AND SINGLE.}

Robinson Crusoe, profusely illustrated................ CExrs.

The Shadow Pantomime-A miniature theatre for the little ones...... 30

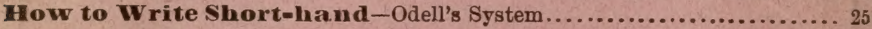

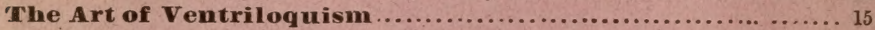

Dur Boys' and Girls' Favorite Speaker.................... 20

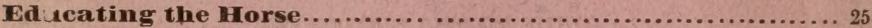

Every Lady Her Own Dressmaker........................ 20

Napoleon's Oraculum and Book of Fate................... 15

The Complete Guide to Swimming and Skating............ 20

The Happy Home Songster............................... 20

The Fireside Songster................................... 20

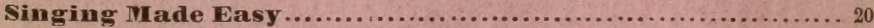

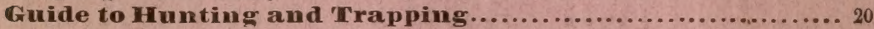

The Black Art, Fully Exposed and Laid Bare............. 25

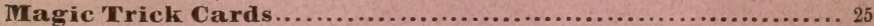

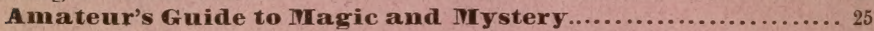

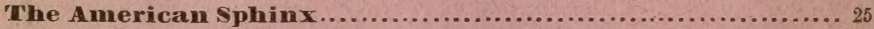

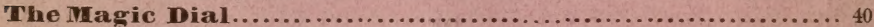

The Dancer's Guide and Ball-room Companion.......... 25

Kove and Courtship Caras............................. 30

Leisure Hour Work for Ladies........................... 20

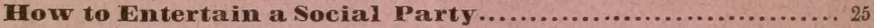

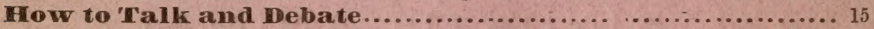

The Model Letter-Writer................................ 15

How to Behave............................................. 15

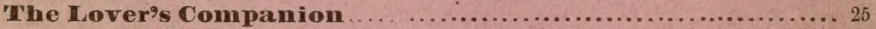

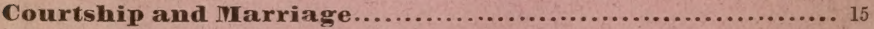

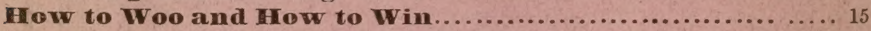

The Complete Fortune-'Teller and Dream-Book $\ldots \ldots \ldots \ldots \ldots 15$

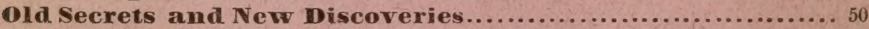

Laughing-Gas, with comis illustration.......................... 25

Salt, Pepper and Mustard-A book of fun...................... 20

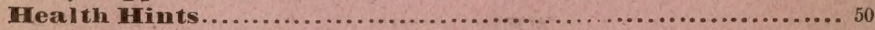

Preserving and Manufacturing Secrets................. 50

Secrets for Farmers...................................... 30

The Common-Sense Cook-Book........................... 25

The Housew ife's 'Treasure $\ldots \ldots \ldots \ldots \ldots \ldots \ldots \ldots \ldots \ldots \ldots \ldots \ldots . \ldots \ldots . \ldots \ldots$

If you have not one, send stamp for a catalogue.

Address
FIRANK M. REED,

139 Eighth Street, New York. 


\title{
LIFE IN THE BACK-WOODS:
}

\author{
- A GUIDE
}

TO THE

\section{SUCCESSFUL HUNTING AND TRAPPING}

OF

ALL KINDS OF ANIMALS.

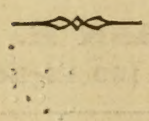

PUBLISHED BY

FRANK M. REED.

NEW YORK. 
GRIMI CARE, anxiety, moroseness, all this rust of life, ought to be scoured off by the oil of mirth. It is better than emery. Every man ought to rub himself with it. A man without mirth is very like a wagon without springs, in which every one is caused disagreeably to jolt by every pebble over which it runs. Therefore, whenever the opportunity occurs, laugh-a hearty, rollicking, explosive laugh-which you can do at any time, on short notice, by sending for the following two books:

\section{LAUGHING GAS :}

A Repository of Fun, Wit, and Humor. Containing the richest Comical Stories, side-splitting Jokes, humorous Poetry, quaint Yarns, brightest Scintillations of Wit, profusely Illustrated with funny Engravings. Altogether, it contains the merriest thoughts of the merriest men. Mailed for 25 cents.

\section{SALT, PEPPER AND MUSTARD; Or, Spice for the Million.}

The latest, greatest, and funniest of all "phunny" books. Everybody wants it. It is just the thing for a spare hour, a rainy day, or a wintry evening, to make your dinner digest well. About five minutes after flnishing it, take a dip into " Salt, Pepper and Mustard," ănd you will never be troubled by indigestion or dyspesia. But don't send for it unless your buttons are well sewed on. Ready-made clothing stands no sort of a chance when "Salt, Pepper and Mustard" is being read and deroured. Finally, don't buy and carry it home if any of your friends have weak backs; they couldn't endure it for a single moment. It has ruined thousands of sober faces forever. Mailed for 20 cents.

Address FEATE TH. TEED,

139 Eighth Street, New York.

If you have not a Catalogue of my books, send as stamp to above address, and a beautifully-illustrated. Catalogue wili be sent you.

THIS BOOK IS

Entered according to Act of Congress, in the year 1874, by FRANK M. REED, pr.

In the Office of the Librarian of Congress, at Washington, D. C. 


\section{HUNTING AND TRAPPING.}

Season for Trapping.-All furs are best in winter; but trapping may be carried on to advantage for at least six months in the year, that is, any time between the first of October and the middle of April. There is a period in the warm season, say from the first of May to the middle of September, when trapping is out of the question, as furs are worthless. The most trapping is done late in the fall and early in the spring. The reason why furs become worthless in summer is, that all fur-bearing animals shed their coats, or at least lose the finest and thickest part of their fur as warm weather approaches, and have a new growth of it in the fall to protect them in winter. This whole process is indicated in the case of the muskrat, and some other animals, by the color of the inside part of the skin. As summer approaches, it becomes brown and dark. That is a sign that the best fur is gome. Afterward it grows light-colored; and in winter, when the fur is in the best condition, it is altogether white. When the pelt is white, it is called prime by the fur-dealers. The fur is then glossy, thick, and of the richest color; and the tails of such animals as the mink, marten, and fisher, are full and heavy. Beavers and muskrats are not thoroughily prime till about the middle of winter. Other animals are prime about the first of November. There is probably some variation with the latitude, of the exact period at which furs become prime, the more northern being a little in advance. Trappers are liable to begin trapping too early in the season; conseqnently much poor fur is caught, which must be sold at low prices, and is unprofitable to the trapper, the fur-buyer, and the manufacturer.

Figure-Four 'Trap.-The "figure-four," which forms the basis in the construction of a large variety of traps, is made of three 
sticks-an upright, a diagonal piece, and the trigger, or horizontal piece. The first may be made say eight inches in length, the upper end being whittled to a thick edge - not a point. The horizontal piece, or trigger, about ten inches long and square, has a notch on one side, about seven inches from one end. On the upper face of the trigger, about six and a half inches from the side noteh, is another notch. The diagonal has both ends beveled or brought to a wide edge, and a notch cut near one end. - In setting up the figure, hold the perpendicular up, fit the trigger to its side, taen adjust the notch in the diagonal to the perpendicular, and then insert the other end of the diagonal in the notch near the end of the trigger. Now let the lid of the trap or the fall, whatever it may be, rest on the end of the diagonal immediately over the trap. This makes the figure-four stand firmly, yet ready to fall at a very slight pull upon the trigger, to which the bait is fastened - the trigger extending some three inches from the perpendicular.

Sieve Trap.-Take a large sieve and prop it up with a stick, to the middle of which one end of a piece of string is tied. Strew some crumbs of bread or seeds under the trap, and also a few near by; and, taking the other end of the string in your hand, retire and conceal yourself at some distance, until the birds are attracted by the bait. As soon as you perceive them feeding directly under the trap, jerk the string quickly and the sieve falls. This is the simplest of boy's traps, but answers very well when there is time to spare. When a chickon is wanted about the farm-house, it is often time saved to catch it in this way.

Quail Trap.-A quail trap may be any kind of coop, supported by a figure 4 . The spindle of the figure must either be so made as to hold grain, or, what is better, some grains of wheat or buckwheat are strung over a strong thread with the aid of a needle, and tied to the spindle. Quails and prairie-hens easily enter a trap when the ground is covered with snow. At other times it is rather difficult to catch them.

Gopher 'Trap. - Take a hard piece of wood, about nine inches long, and turn it so that one end will be two and a half inches in diameter and the other end three inches, gradually sloping from one end to the other. With a two-inch auger bore a hole in the small end eight inches deep. Then take a fine-toothed rip-saw and split it open from end to end in two equal parts. In one of these halves a spring door is fixed, made of sheet-iron, which is round like the opening and curved to fit down in the half. This is made fast on a hinge near the 
entrance, with a spring under it sufficient to raise it to a perpendicular, the hinge so arranged that it can only be raised to a perpendicular. Another piece of sheet-iron, made round to move easily in the two-inch opening, is made, which is attached to a long, narrow strip of iron, which strip moves easily under two staples in the bottom of the half to which the door is fastened. In order to set the trap, the door is pressed down, and the end of this strip projects over it, and thus holds the door open. Then take the two halves and put them together, and slip over them a thin wide ring, made sloping like the trap, and it is ready for use. With this trap you go out where the gopher is at work, and find his last made billock, and if it is not quite finished, all you have to do is to stick the trap in the hole, open end downward, and in a short time he will bring up his load of dirt, and, in pressing against the upper piece of iron, he will push the strip of iron from over the door, when the spring will lift it up and shut him in.

Farmer's 'Trap, for Mink, Weasels, Skunks, \&c.Take boards half-an inch thick, and make a box the two sicies and top 12 inches long, with one end closed; the size of the box inside being 4 inches square. A steel spring is fastened on the closed end of the box, to which is fastened a square ring at its extremity, through which the game thrusts its head to reach the bait at one end of a catch, which holds the ring depressed and held by a wire running from the frout end of the trap to the catch on the upper extremity of the bait hook. One who has tried it extensively says: "This is the best trap for skunks in the world, I believe. I have used many different kinds, but none work so well as this. You can set it at the hole in a wall or fence. It is sure fire."

Hawk and Owi Traps.-To catch hawls or owls, take a pole 20 feet long, to be set a short distance from the house or barn or on the poultry house. Split the top so as to admit the base of a common steel irap, which should be made fast. When both trap and pole are set you may be sure of game of some kind. 'These birds naturally light on high objects such as dead branches of trees or tops of stacks, and one should use judgment about the place where he puts the traps. An open field, near the chicken yard, is probably best.

Bsird Lime. -1 . The midale bark of the holly, any quantity; boil it for seven or eight hours in water, or until it is soft and tender, then drain the water off, and place it in pits under ground, surround. ed with stones; let it remain to ferment, and water it if required until it passes into a mucilaginous state. Then pound it well and wash it 
in several waters; next leave it for four or five days to ferment and purify itself. -2. Linseed oil boiled and burned down to a thick varuish answers even better than the above. In preparing it the oil is put into an iron kettle and set upon a fire; when warm it is lighted also and allowed to burn until it is of the destined thickness. The iron pot should not be over one-third full of oil, and should have a lid to fit pretty closely, by which the oil can be quenched at will. From time to time this must be done to ascertain the condition of the oil. It takes from nine to ten hours to boil it down, and when done, it should be put away in a vessel as nearly air-tight as possible, otherwise it will continue to grow thicker and thicker until it becomes unusable. It should be of the consistency of thick syrup.

How to Use Bird Linne.-There are various methods of using it. It can be either employed on sticks made for the purpose, by which means there is not so much loss of bird lime, or plastered on spots to which the birds are accustomed to come. If used in the former way, holes must be bored into the tree in which to fix the limed sticks. Birds taken with lime should be relieved as soon as caught, or they will flutter themselves to death. Alcohol will wash off the lime. But take care in applying it; small birds can be killed with the smell of alcohol. If their heads are not limed, cover that part of them with a silk handkerchief, and use a sponge to wash off the lime.

Snares.-Snares are not very certain, but they are little trouble to make. They must be set in the paths or runs of the birds it is intended to take. They are of horse hair or thin copper wire tied in a running knot. The tendency of every bird when it finds itself touched about the head is to push forward. This draws the knot tighter, until the bird kills itself.

'To Trap Squirrels. - In trapping squirrels, set a steel trap on the upper rail of a fence near where they frequent; set a pole with an ear of corn, or some other squirrel food fastened to the end of it, up against the side of the fence, leaning in such a position as to spring the bait over the trap at a height of six or nine inches; when the squirrel reaches to get the bait he will get into the trap.

Head Fall reap.-The simplest dead fall is made with one $\log$, heavy enough to hold the creature which it is proposed to trap. Cut a notch into a stump, or drive a short stake with a notch in it, or fasten the log with a withe to a stake or sapling, or in any case allow it a hinge-like motion. This is done with the log lying on the gromnd. 
Raise one end and support it upon a figure-four, baited of course (see description hereafter). The bait stick of the figure-four must be at right angles with the log, and inclosed with stakes or otherwise to allow the animal to approach only from one side, and obliging it to stand across the line in which the $\log$ would fall. Another way is to arrange two logs, one to fall on the other in the same way. Stakes may be driven at the side, if found necessary, to insure one log falling on top of the other.

To Trap Gophers,-Go where they work; find the last mound made; open the hole, set in a common spring trap, cover with a little light sand; leave the hole open. The gopher will come to close the hole, and get trapped.

To rerap Pis krat.-Find a log with some recent droppings of the muskrat on, it; a notch is cut in the log for the trap, an inch or two under the water. The trap is fastened to a tally-stick. These tallysticks are green saplings with a fork at the upper end, and a hook near the bottom to hold it in the loose ground. The chain-ring is slipped on to this tally-stick, and care is taken to so place the tally-stick and trap that when canght, the muskrat shall take to the water and be drowned. If on the land, among weecis and bushes, he will not unfrequently twist off his leg and escape. The traps are also placed in the runs, on bogs and old muskrat bouses, and wherever there are recent indications that the muskrats come to feed. Where the game is scarce, the traps are sometines baited, but otherwise this is not necessary. Carrots, parsuips, apples, potatoes, or a piece of the flesh of a muskrat can be used for bait. A stick is stuck in the ground, slanting in such a manner that the end shall be 6 or 8 inches above the treddle of the trap. The bait is stuck on the end of the stick, and in this way, if there are any rat; in the vicinity, you are pretty sure to catch tham. Sometimes the traps are covered with an inch or two of weed: and some trappers put a drop or two of the oil, found in the glands of the muskrat, on or near the traps. The next morning the hunter takes his boat and visits his traps.

To Trap THink.-For mink the trap should he set near some stream. If their holes cannot he found, make one. Set the trap in the cavity, three sides of which should be barricaded with stones, bark, or any equivalent substance. Place the bait at the farther extremity of the cavity, beyond the trap. Bait with any kind of fresh meat; muskrat meat is good, but fish, either fresh or stale is better. Bait should be smoked in cold weather, to give it a stronger smell. 
The best scent for attracting mink is prepared from tne decomposition of minnows, eels, or trout. Cut the fish into small pieces; put into a bottle, cork loosely, and let it hang in the sunshine two or three weeks in the summer. A few drops of this on the bait, or on a stick near the trap, will draw mink a long distance.

To Trap Foxes.-The trap should be well smeared with blood, or beeswax, to destroy the odor of the iron. Set it in soft earth, packing moss or leaves lightly around the pan and jaws. Bait with fried meat. An old trapper says: "To make the allurement doubly sure, obtain from the female of the dog, fox or wolf, the matrix, in the season of coition, and preserve it in alcohol, tightly corked. Leave a small portion of it on something near the trap; also, when visiting the traps, put some on your boots." Another method is to make a bed of chaff in the open field, in a locality the fox is supposed to visit, but where it will be least likely to be visited by passing hunters. Visit it daily, and stir into the chaff, very old or toasted cheese, or scraps of meat made fine, using the utmost caution not to change the appearance of the bed or its surroundings, and making as few tracks as possible. The materials of which the bed is composed should not be handled any more than is absolutely necessary. Too much care cannot be taken in making the bed; for if foxes are plenty, and you get several to visit it, it will last for some time, and will afford you a great deal of amusement. As soon as you are satisfied a fox has visited the bed regularly for five or six nights, you may put in your trap. It should be a small sized double spring, and should be fastened to a clog, light enough for the fox to drag, but heary enough so that he cannot get too far away; though if there is snow on the ground, there will be no difficulty in finding him, if he goes some distance. He may be caught the first night, but more likely than not, will dig out your trap, or show his contempt in some other way, compelling you to bring into force all your ingenuity, before your efforts are successful.

To Trap Fabbits. - To trap rabbits, take brass wire, muke a noose large enough for them to put their head through; then trim a small tree near their road, fasten the wire to the top, bend over and fasten by a notch to a peg driven in the ground; then make a fence of fine brush a little across their road, leaving a hole to hang the wire in. Some use box traps, baited with sweet apple; also steel traps laid in their roads and fastened. 


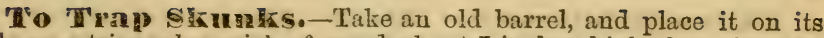
side on a triaugular stick of wood about 7 inches high, fastening the bait on the bottom of the barrel. When the skunk goes for this bait as soon as he passes the centre the barrel turns up with the skunk, without making any scent. Then take it by the tail and do with it as desired. Care must be taken not to place the barrel too high, as it might throw over and not remain upright. The more skunks you catch in the same barrel, the better the trap.

To Destroy Groand Moles.-There are several mole traps in market that work well, provided the moles can be induced to go where they will be caught. In addition to the traps, set men to watching the moles during light showers in summer, at which time they are more active, and when one is found moving the soil he is to be dug out and killed. More moles have been caught in this way than with all the traps used. Poisons of various kinds have been recommended, but on trial they have proved worthless.

To catch Iruskiats without Traps.-It is a mystery to many how muskrats, beavers, and other animals, are able to stay so long under water, apparently without breathing, especially in winter. The way they manage is, they take in a good breath at starting, and then remain under water as long as possible. Then they rise up to the ice and breathe out the air in their lungs, which remains in a bubble against the lower part of the ice. The water near the ice is highly charged with oxygen, which it readily imparts to the air breathed out. After a time, this air is taken back in the lungs, and the animal again goes under the water, repeating this process from time to time. In this way, they can travel almost any distance, and live almost any length of time under the ice. The hunter takes advantage of this habit of the muskrat in the following manner. When the marshes and ponds where the muskrat abounds are first frozen over, and the ice is thin and clear, on striking into their houses with his hatchet, for the purpose of setting his trap, he frequently sees a whole family plunge into the water and swim away under the ice. Following one for some distance, he sces him come up to recover his breath, in the manner above described. After the animal has breathed against the ice, and before he has time to talie his bubble in again, the hunter strikes with his hatchet directly over him, and drives him away from his breath. In this case he drowns in swimming a few rods, and the hunter, cutting a hole in the ice, takes Lim out. 
To catch IRaccoon.- - The surest way to catch them is with a good cur dog. One that will not give tongue on track but will bark at the tree. But if you wish to trap them with steel traps, go to the woods, near a swamp, find a big log lying in or near the swamp, set your trap on the log and then get two old limbs, set one on each side of the log over the trap, crossing at the top, forming an $\mathrm{x}$, so that the coon will have to go under them and over the trap. Bait if you choose with frogs or chicken. But whether you bait or not the coon will run the old $\log$ if he comes in the neighborhood. Or on the same plan you can set a dead-fall.

lints one the value of Skins.-The skins of animals trapped are always valued higher than those shot, as shot not only makes holes, but frequently plow along the slin making furrows as well as shaving off the fur. To realize the utmost for skins they must be taken care of, and also cleansed and prepared properly. Newhouse gives these general rules, derived from experience.

1. Be careful to visit your traps often enough, so that the skin will not have time to get tainted.

2. As soon as possible after an aninial is dead and dry, attend to the skinning and curing.

3. Scrape off all superfluous flesh and fat, and be careful not to go so deep as to cut the fibre of the skin.

4. Never dry a skin by the fire or in the sun, but in a cool, shady place, sheltered from rain. If you use a barn door for a stretcher (as boys sometimes do), nail the skin on the inside of the door.

5. Never use "preparations" of any kind in curing skins, nor even wash them in water, but simply stretch and dry them as they are taken from the animal.

T'o skim Tluskrats. - The muskrat is usually skinned by beginning at the head, ripping from the chin to between the fore legs, and then stripping the skin off over the body. When taken off in this manner the skin is stretched on a bent rod of tough, pliable wood. When skinned from the tail it is stretched on a board.

T'o prepare Haccoon Skins.-The skin of the Raccoon should be nailed to boards to dry, then treated to a paste of $1 \mathrm{oz}$. alum; 1 oz. salt; about $\frac{1}{2}$ draohm sulphuric acid; 2 gills water, and a little wheat bran. It should when dry be scraped off with a spoon or other thing as in case of mink skins. To work the skin soft, instead of nailing it on boards, roll it up and work it soft. 
To Deodorize \$kunk Skins. - To deodorize Skunk skins or articles for clothing scented, hold them over a fire of red cedar boughs, and sprinkle with chloride of lime; or wrap them in green hemlock boughs, when they are to be had, and in 24 hours they will be cleaned.

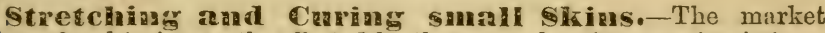
value of a skin is greatly affected by the care taken in removing it from the animal, and in drying it. The common way is to tack the skin to the barn-door and let it remain stretched until quite dry. The trapper in the woods having no such convenience as the barn-door at hand, is obliged to resort to other methods. One plan is to dry the skin on a hoop. A skin to be dried in this manner must not be ripped down the belly, but it is cut from the lower jaw of the animal to just below its forelegs; the lips, eyes, and ears being cut around, the skin is stripped off, leaving the fur side inward. The hoop consists of a branch of hickory or other elastic wood, an inch through at the butt. This is bent and pushed into the slin, which is drawn tight, and fastened in place by notches in the bow, drawing the skin of the lip. into these notches. A much neater way, and one generally preferred, is to use stretehers of thin wood. As t'lese have to be carried by the trapper, they are made of light wood and very thin. They are threesixteenths of an inch thick, 20 inches long, 6 inches wide at the larger end, and slightly tapering. They are rounded to a blunt point at the lower end, and the edges chamfered. The skin is drawn over the board, and secured with tacks. Skins stretched by either of these methods should not be dried in the sun nor by a fire, but in a cool place where they will be sheltered from the rain. No salt or other preservative is used upon skins intended for the market.

Baits for Fis laing-Fish, in their natural element, take such baits as the changing seasons produce, and will not at one time of the year bite at the same bait which they may be caught with at another; for instance, in the spring and autumn, worms may be used all day long, but in summer, worms must only be used early and late, morning and evening. An earth-worm is naturally the first bait the young angler looks out for: it is always to be had, is put on the kook without difficulty, and (excepting at the times above stated) may always be used for certain kinds of fish, with the certainty of hooking something, if proper patience is used. When baiting with a worm, the hook should be put in close to the top of the worm's head, and then passed carefully down, gently working the worm up the hook at the 
same time. Not more than a quarter of an inch of the worm shoula be left hanging over the hook. To scour or starve these worms, and get rid of the earthy matter they contain, they must be placed in damp moss, not soddened with water, but only damp. In creeping through the fibres of the moss, they compress and empty themselves. The ashgrub, which is found in the rotten bark of a tree that has been felled some time, is an excellent bait for all small "pan " fish, such as chub, sun-fish, perch, etc., and may be used all the year round; it should be kept in wheat bran. All grubs or worms make good bait for little fresh water fish. Grasshoppers are good baits during June, July, and August; their legs and wings must be taken off before they are put on the hook. Shrimp are good for bass, tom cod, and lafayette fish. Crab and clam are good bait for these also, shedder crab especially. Take some old cheese and the crumb of white bread, and mix them up to a tolerable degree of consistency, and you will make a good bait for chub. (White Bread Paste.) Knead crumbs of white bread dipped in honey in the palm of your hand until they attain a fair degree of consistency: it is good for small fish. (Wheat Paste.) Procure some new wheat, remove the husks, and afterward pound it; then pour some millk or water over, and gently simmer the composition; when cold, it will be somewhat like a jelly, and a very small piece only should be put on the hook. Paste baits are not all adapted for swift, running streams, but for quiet brooks, pon ls, or very still rivers; you must be sharp of eye, and quick to strike, otherwise both fish and bait will give you the slip. A quill float is better than a cork one when baiting with paste, as it betrays the slight st nibble.

Hooks for Fishing.--Hooks are of various patterns and sizes, beginning at No. 1, which is the largest salmon size, and ending at No. 14, called the smallest midge. American hooks are also very good, especially those made by Clarke's patent. Limerick hooks are excellent; and those made in Dublin, marked with 2 F's, 2 B's, and so on, are second to none. A bad hook, be it remembered, is worse than a bad knife, only fit to be thrown away. When fastening the hooks on your lines, use strong but fine silk, and if you can get it near the color of your bait, so much the better; wax the silk thoroughly with shoemaker's wax, and wrap it four or five times round the body of the hook, then place the gut or hair on the inside of your hook, and continue winding the silk tightly round till you have wrapped it about three parts down the hook. Whipping is finished off by slipping the end of the silk through the last circle, and drawing it tight. Knotting, by laying two pieces of gut or hair together, 
one overlapping the other some three inches or so, then holding one end in the left hand, while forming a simple slip knot on it; then turning the other end to the right, and doing the same; after that drawing the two together, when the knot is complete. No direct pull will ever unloosen this water knot, though it can be undone easily. Gut is obtained from the silk worm. Gimp is any kind of tackle covered with fine brass wire, to protect it from the teeth of fish, sharp stones, or other injury.

Ground Bait for Fishing.-Ground baiting is a most essential part of angling, and ought never be omitted, as success in bottom or flnat fishing cannot be expected, unless the proper means for drawing the fish together are resorted to. The object for throwing bait into the water is to collect fish to one particular spot, and then to use superior kind of bait, though of a similar kind, on the hook. Thus, if going to angle with earth-worms, throw in for ground bait those that are unscoured, and fish with those that are well scoured. For small creek fish, mix bran and clay together into lumps about the size of an apple; place some grubs in the middle, and close the clay over them. It is a very useful bait in a still pond, hole, or slight eddy. Or take the crumb of white bread, soak it in water, squeeze it almost dry, add bran, and work them up together until they acquire the consistency of clay. Brewer's grains will also be found very serviceable; they must be perfectly fresh. Grubs, worms, the toughest part of crabs, lobsters, or clams, may be thrown in without taking the trouble of working them into balls or clay, if the water is perfectly still; but if you are fishing in a stream, such a system of ground baiting is injurious, as they are carried away by the stream, and $\mathrm{d}$ aw the fish from the spot.

Fish Charms. - The so-called fish charms, as given in many books and retailed as great secrets, are as a rule a mass of nonsense, and when employed successfully make the fish caught undesirable for eating, impregnated more or less as they must be, with the "charms." These remarks apply also to the aluore "Chinese art of catching." The only legitimate way of catching fish is by the hook and net, and no other should be resorted to. Some of these "secrets" are as follows-For bait, take a handful of swamp-apple blossoms; put them in a glass jar or bottle, together with a gill of rum; cork the bottle tight and let it stand in the sun for three or four hours, then take half a pint of water that is found in places where grows the plant commonly termed flytrap. This plant, the botanical name of which is dioncea muscipula, vegetates in quag moss around fresh ponds. Sat- 
urate your bait with the liquid two or three hours before using. The liquid should be kept in a wooden or earthen vessel. Another is to put the oil of rhodium on the bait when fishing with a hook, and you will always succeed; or, take the juice of smallage or lovage, and mix with any kind of bait. As long as there remain any lind of fish within many yards of your hook, you will find yourself busy pulling thern out. Or, get over the water after dark, with a light and a dead fish that has beem smeared with the juice of stinking gladwin. The fish will gather around you in large quantities, and can easily be sconped up.

Japanese Ant of Catching Fisllo-Take Cocculus Indicus, pulverize and mix with dough; then scatter it broadcast over the water as you would sow seed. The fish will seize it with great avidity, and will instantly become so intoxicated that they will turn belly up on top of the water, by dozens, hundreds or thousands, as the case may be. All that you now have to do, is to have a boat or other convenience to gather them up, and as you gather, put them into a tub of clean water, and presently they will be as lively and healthy as ever.

Fishing without Nets, Lines, Spears, Smares, "BBotbs" or Bait.-The following plan we have known used with great success to catch fish in winter, in Pennsylvania. Where the water was clear and still, say the back water of a dam, it would often freeze hard enough to make good skating and yet the ice would be so clear that the fish could be seen lying at the bottom or lazily moving about. By striking the ice (not too hard) immediately over the fish, a sufficient concussion would be produced to stun the fish. It would immediately turn over and come up to the ice, its white belly showing clearly against the ice below, when we proceeded to cut a hole and take out the fish. A mallet generally was used to strike the ice, as we produced a stunning blow with it without killing the fish, as would be likely to occur were the blow struck with the poll of the ax. On taking the fish home and putting them into water-although some or all would be frozen stiff, quite a number would often revive, and it was to produce this result that the mallet was preferred to strike with.

Hov to Clnose Gras.-Whatever may be the particular nake you prefer, let your gun be a good one. If you are not competent to select yourself, it would be best to obtain the aid of some capable and reliable friend; and we recommend you to purchase of some 
dealer of established reputation. The claims of the different makers can, in most cases, be ascertained from their respective circulars. Breech-loader's have several important advantages; thougin many sportsmen retain a preference for the old-fashioned muzzle-loading gun, for its supposed superior shooting powers. In every other respect the first rank seems conceded to the breech-loader; with it the sportsman's hand need never be at the muzzle under any circumstance. It is far more expeditiously used, as powder, shot, cap, and wadding are all inserted in the barrel at the same time; and it is far more easily cleaned, as all that is required is to draw a piece of flannel attached to a string through the barrels once or twics after a day's shooting.

How to Clean \$inot-Grans.-First place your hammers at half-cock; draw out the ramrod and bolt; then lift the barrels from the stock, and you are ready to wash. Place the barrels in cold water, being careful the water is clean and that there is not any dirt or sand in the pail; then if you have the three-jointed washing-rod, with the necessary implements that accompany it, first use the brush until you have removed most of the dirty powder; next take tow, and wash until you have gotten it perfectly clean; then take soft cotton rags, and dry it out thoroughly. It is best to rub the barrels until they feel warm to the hand; then you may know your gun is dry, and in no danger of rusting. Hot or boiling water should neverbe used in the cleaning of a shot-gun becuuse it will-can not help-injuring the "temper" of it.

Tink-Freeding.-To Trap Young Mink.-Adult minks are almost untamable, but young ones readily submit to handling, and are easily domesticated. The time to secure young minks is in May and? June, when they begin to run with their dams. The streams must be quietly watched for mink-trails, and these tracked to the nest. When they leave the hole the old one may be shot, and the young ones secured, or they may be dug out. Those who own a breeding stock of minks ask high prices for them; but trappers represent to us that it is an easy matter, with a little patience, to get the wild young ones.Habits. A successful breeder says that he does not attempt to tame the wild mink, but only aims to supply for it in a small space all the necessities of its natural instincts. He says the mating season commences about the first of March, and lasts two weeks, never varying much from that date. The female carries her young about six weeks. In the minkery, where diet, water, temperature, etc., are similar with each animal, there is so little difference in the time of mating and timo 
of bearing young in different animals, that five out of six litters dropped last spring, were born within twelve hours of each other. The young are blind from four to five weeks, but are very active, and playful as kittens. The mother weans then at from eight to ten weeks old. At four weaks the mother begins to feed them meat; this they learn to suck before they have teeth to eat it. The nests in which the young are born are lined by the mother with soft material, and are made in the hollow of some old stump, or between the projecting roots of some old tree, and always where it is perfectly dry. The nest is located near pure running water, which the mother visits twice every twentyfour hours. She feeds her young on frogs, fish, birds, mice, crabs, etc., etc. The mink is from birth a pattern of neatness and cleanliness, and as soon as a nest begins to get foul and offensive, she takes one of the young in her mouth, and depositing it in a clean, suitable place, builds a nest about it, and then brings the balance of the litter. She feeds and cares for them until they are three and a half or four months old. When the young are weaned, about the 10 th of July, she builds her nest near the water, in which the young soon learn to play. There are usually four in a litter, though the number ranges from two to six. Towards fall the mother separates them into pairs. One pair - or if the number be odd, the odd one-is left in the nest; the other pair, or pairs, she places often half a mile from each other, and then seeks new quarters for herself. The young soon separate, and each one catches his own frogs. They do not pair, but the male is a sort of rover and free-lover. Minks are unsociable, petulant, vicious in play, savage in war. Late in the fall they establish regular rumways from one stream to another, and usually under brush, fallen trees, weeds, swale, and under banks, - anywhere, in fact, where they can avoid the sunshine and escape the chances of observation. The mink is a sure prophet, and just before hard winter begins, he lays by a store of food for the winter in safe places, near his winter nests, of which he has several. As the snows fall he burrows under the snow, where he remains until about February, when his supply of food is exhausted and he is forced to search further for food.-Management of. Mink being by nature solitary wandering creatures, being seldom seen in company except during the breeding season, are therefore impossible to be reared successfully, if large numbers are lept constantly together; therefore their inclosure should be a large one. The male and female should be permitted to be together frequently from the middle of February until the middle of March. At all other times keep them entireiy separate. The young mink make their appearance about 
the first of May. When wild in the woods they will seldom vary five days from this time; but when kept in confinement there is greater variation. About this season they should have plenty of fine hay, which they will carry into their boxes to make nests. A box three or four feet long and eighteen inches wide is the shape they prefer; it should be placed as far as possible from the water, to prevent the mink from carrying water and mud into it. The young mink when first born are small and delicate, destitute of any kind of fur, and muci resembling young rats. If the old mink is tame, the young ones may be taken out of the nest and handled when they are three weeks old. They will soon learn to drink milk, and may be fed every day. At five weeks old they may be taken from the mother and put into a pen by themselves, when they will soon become very playful and pretty, and make much better mothers than they would if allowed to run with the old ones. The shelter should be in the shape of a loug box, five or six feet wicle, and three or four feet high, set upon legs, and with a good floor and roof. Divide it into separate apartments, six feet long (or longer would be better), the front of each apartment to be furnished with a swinging door of strong wire screen, with the hinges at the top, and a button or some kind of fastener at the bottom. A trough, six inches square, macle by nailing three boards together, should run the whole length of the pen on the back side; one end of the trough should be made several inches lower than the other, so that the water can be drawn off. With this arrangement the water can be turne 1 in at one end of the trough, and be drawn off and changed as often as desired. The lower end of the trough should be a little deeper than the other, to prevent the water from running over. Each apartment is furnished with a box three feet long and eighteen inches wide. On one side of the box and near one end is made a round hole, two and a half inches in diameter, and provided with a sliding cover, so that by means of a stick it can be opened or closed from the outside. This is so the mink can be shut up when the pen is being cleaned out. On the top of the box and at the other end should be a door large enough to put in hay for the nest and take out the young. It is necessary that they have abundance of pure, soft water, fresh air, desirable shade, and plenty of exercise. These conditions secure to the mink a good quality of dark fur, and good health. Brush, weeds, etc., are allowed to grow in the yard, but not near enough the wall to admit of their climbing up and out.

Dressing and Tanning Skins and Fur's.-The cheapest and readiest as well as the best method of dressing skins for use 
with the hair or wool on, is to first scrape off all the fat with a knife rather blunt on the edge, as not to cut holes into the hide, upon a round smooth log. The log, for convenience saire, should have a couple of legs in one end, like a trestle; the other end should rest upon the ground. After the fat is well cleaned off, take the brains of the animal, or the brains of any other recently lilled, and work them thoroughly into the hide. This renders the hide pliable. Then to preserve from the ravages of insects, scatter on it some powdered alum and a little saltpetre. If the hair side has become greasy, a little weak lye will take it out. Sheepskins may be dressed in the same way, though the wool should be cleaned with soapsuds before using the brains. Another way, but more expensive, is to use a paste made of the yolk of eggs and whiting instead of brains, working it in the same way, letting it dry and brushing off the whiting. Then add the powdered alum as before. Deerskins and eren small calfskins are often tanned, as the process is called, with the hair on, for garments. If it is desired to give the decrskin a yellow color, yellow ochre or chrome yellow may be used in combination with the brains, or yolk of eggs, and afterward brushed off.

To Tan leat t'ien put it in lime; take it ont, and remove the hair by rubbing it, and soak it in clear water until the lime is entirely out. Put one pound of alum to three of salt, dissolve in a vessel sufficiently large to hold the hide; soak the hide in it three or four days, then take it out, let it get half dry, and then beat or rub it until it becomes pliable. Leather prepared by this process will not do so well for shoes, but answers well for ham-strings, back-bands, and various other purposes on the farm.

To Cure Green Giriales.-A great many butchers do not use proper care in this branch, and the consequence is that the hides will not pass city inspection, owing entirely to the ignorance and carelessness of persons preparing them for market. The proper way to salt hides is to lay them flat, flesh side up, and form a nearly square bed say twelve by fifteen feet, folding in the edges so as to make them as nearly solid as possible. Split the ear in the cords that run up the ear in each one, so as to make them lie out flat. Sprinkle the hide with two or three shovelfuls of coarse salt, as the size may require, say for a sixty or eighty pound hide, from ten to fifteen pounds of salt. At any rate cover the hide well, as it need not be wasted; th $n$ let them lie in this from twelve to twenty dajs, after which take them up, shake the salt out, and use it again. 
T0 Tan Squivel-Skins.-Place them in a vessel with s:rong wood ashes. Thet the ashes till they will make a mortar. Leave them in about nine days, or until the hair can be pulled off; take them out and remove the hair. Then place them in strong soft-soap six days; then remove and wash them in cold water till all the soap is out of them. When nearly dry, rub them with the hands till dry. (With the hair on.) Place the hide on a smooth, round-sided slab, made for the purpose, with two legs in one end, and let the other end rest on the ground; drive a nail in the upper end to hold the skin from slipping while fleshing. Scrape off all the flesh with a blunt knife, being careful not to tear the hide. Then take the brains of the squirrel and work them thoroughly into the skin; this renders the skin pliable. Then scatter on some powdered alum and a little saltpetre. Let dry; then stretch and work it until as pliable as may be desired.

\section{Tamming without Bark or Pineral Astringents.} -The astringent liquor is composed of water, 17 gallons; aleppo galls, $\frac{1}{2} \mathrm{lb}$; Bengal catechu, $1 \frac{1}{2} \mathrm{oz}$; and $5 \mathrm{lbs}$. of tormentil, or septfoil rnot. Powder the ingredients, and hoil in the water one hour; when cool, put in the skins (which must be prepared by being plunged into a preparation of bran and water for two days previously); handle them frequently during the first three days, let them alone the next three days, then handle three or four times in one day; let them lie undisturbed for twenty-five days more, when the process will be complete. -(Canadian Process. ) The Canadians make four liquors in using the japonica. The first liquor is made by dissolving, for twenty sides of upper, fifteen pounds of terra japonica in sufficient water to cover the upper, being tanned.

To Tan IIuskrat-Gkins with the fur on.-First, for soaking, to ten gallons of cold soft water add eight quarts of wheat bran, half pint of old soap, one ounce of borax; by adding two ounces sulphuric acid the soaking may be done in one half the time. If the hides have not been salted, add a pint of salt. Green hides should not be soaked more than eight or ten hours. Dry ones should soak till very soft. For tan liquor, to ten gallons warm soft water add half a bushel brau; stir well, und let stand in a warm room till it ferments. Then add slowly two and a half pounds sulphuric acid; stir all the while. Muskrat-hides should remain in about four hours: then take out and rub with a fleshing-knife-an old chopping-knife with the edge taken off will do. Then work it over a beam until entirely dry.

To Dress eer-Sikins.-Put the skin into the liquid whilo 
warm, viz.: eight quarts rain-water to one pint soft-soap. Warm it. Then punch the hide, or work it with a soft stick and let it lay one day. It is then to be taken out and wrung -rolled between two logsor even a wringing-machine will be better. Then stretch it until it is dry, -in the sun is best, or by a hot fire. Then oil it thoroughly with any oil convenient. It should then be treated to the same bath of suds (heated quite warm), and lay another day. Then pull it out and dry as before. Any oil will do, but good fresh butter is better than anything else. When the skin is dry rub it with ochre, which will give it a splendid yellow color.

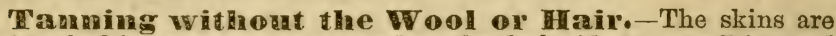
first soaked in warm water, scraped on the flesh side to get off fat, and hung in a warm room until they begin to give a slight smell of hartshorn. The wool or fur then comes off readily. The hair side should now be thoroughly scraped against the hair. The skin is next soaked two or three weeks in weak lime-water, changing the water two or three times. Then they are brought out again, scraped smooth, and trimmed. Then rinsed in clean water, then soaked in wheat bran and water for two or three weeks. After this they are well stirred around in a pickle of alum, salt, and water. Then they are thrown again into the bran and water for two or three days. Then stretched and dried somewhat in a warm room. After this they cre soaked in warm water, and then worked or trodden on in a trough or pail filled with yolk of eggs, salt, alum, flour, and water, beaten to a froth. They are finally stretched and dried in an airy room, and last of all smoothed with a warm smoothing-iron. This makes the beautiful leather we see in gloves, military trimmings, etc. Th 3 proportions for the egg paste are as follows: Three and a half pounds salt, eight pounds alum, twenty-one pounds wheat flour, and yolks of nine dozen eggs. Make a paste with water, dissolving first the alum and salt. A little of this paste is used as wanted with a great deal of water. Chamois skins and deer skins not wanted for gloves, are similarly treated up to the point of treating with egg paste. Instead of using this process they are oiled on the hair side with very clean auimal oil, rolled into balls and thrown into the trough of a fulling-mill, well beaten two or three hours, aired, reoiled, beaten again, and the process repeated a third time. They are then put into a warm room until they begin to give out a decided smell, then scoured in weak lye to take out superfluous grease. Here the intention is merely to get a thick felt-like skin of good color; a nicely grained surface is not required, as in gloves. The skins are finally rinsed, wrung out, stretched, and dried; and when nearly dry, 
slightly rubbed with a smooth, hari, round stick. These are the fine processes. A dried skin oiled so as to become smooth and pliable will retain the hair or wool a considerable time. Or it may be made more durable where the color of the flesh side is no object, by scraping, washing in soap-suds, and then putting directly into the tan-pit. For ordinary purposes rabbit, squirrel, and other small skins can be effciently preserved with tide hir by the application of powdered alum and fine salt, put on the:n when irss, or if not iresh by dampening them first. Squirrel-skins when wanted without the hair will tan very well in wheat-bran tea, the fat and hair having been previously removed by soaking in lime-water and scraping. Old tea-leaves afford tamnin enough for small skins, but they give a color not nearly so pleasant as bran. Almost any of the bariss afford tannin enough for small skins-willow, pine, poplar, hemlock of course, sumach, etc.

Setting Traps.-The first thing to secure in setting your trap, is that the animal will go to it; second, that it shall catch him when he comes; and last, that he shall not be able to get array, when once caught. Next, it is necessary always to smoke the trap in burning hemlock, cedar, or juniper boughs, dipped in the blood of pigs that have just been killed, or letting the blood of a chicken run over it, dipping it in melted fat, or rubbing it while warm with a ball of beeswax. But remember that in baiting a rabbit-trap your hands must never be greasy; there is nothing a rabbit will so quickly avoir as grease of any kind. Now having arranged this, your nexi business must be to induce your animal not to be shy. If you are carrying on trapping in wild woods the surrounding scenery is generally wild enough; but near at home, on the farm, care must be taken to take away the appearance of preparation, and yet preparation must be made. A cautious animal, such as a fox or raccoon, should be invited to come several times before the trap is set. Arrange a place with sawdust, hayseed, chaff, and chicken-feathers, several inches deep; scatter thiough it food adapted to the animal intended to be caught-offal of chickens, bones, and bits of waste neat, fish-heads, etc., if for tox; nubbins of corn, etc., for coon. Leave it, and when you have certain indications, set your trap (free from the iron smell), and cover with the material you have used, scattering bits of food therein as before; the creature you are after will probably be there the next morning, if you have properly secured your trap. Another way is to set your trap under water two or three inches, with the bait above it, hung upon a sapling or spile, so as to make the animal stand upon the trap to get it; or to plant your trap well covered at the foot of an old stump, by tho 
side of a sapling, by the side of a barn, haystack, smoke-house, pigpen, but always covering the trap and hanging the bait above it, so as to make the animal step into it. Last of all, you must secure the trap by a weight of wood or metal, by a bent sapling that pulls it up into the air, or by a weight or stick that will pull it into the water and drown it. A short, light chain ought to be attached to every trap of iron, as animals gnaw with ease through anything like rope or hide. If you are catching animals only to get rid of a nuisance, no spring is necessary; but if for fur, you want to hoist the land animal into the air, where they cannot damage themselves; and if water animals, you want to drown them quick. The former result is attained by bending over a sapling with a stout cord attached containing the bait; a portion of the cord continues down to the trap, and is fastened slightiy by a notched peg driven into the ground; when the animal is caught, its struggles free the cord, and the sapling springs back and hoists it into the air. If your trap is set in water it may be fastened by a ring at the end of the chain to a pole running out into deep water; the pole should be fastened into its position and securely anchored, or the whole thing may be rolled far down the stream when you come to look for it; the struggles of the animal caught cause the ring to go farther and farther down the stick, and the weight of the trap finally drowns the animal.

Baiting Traps.-Strong-smelling substances are the best baits, other things being equal; and if the smell of the kind of animal to be caught can be given to the bait in any way, it will be sure to lure the animal to the trap. If a fox-skin be dragged along the ground in the direction of the trap, every fox striking the trail will follow it up. So it is with other animals. Beaver-bait is made thus: The castor or bark stone, which is found in the male beaver, is pressed from the bladderlike bag which contains it into a vial with a wide month. Five or six of these stones are taken, and a powdered nutmeg, a dozen or more cloves, a teaspoonful of ground cinnamon, all mixed with alcohol or whiskey until it is about as thick as good syrup. Cork the bottle, and keep three or four clays. In using this, it should be employed for attracting the beaver toward the trap, but not be put into it. For the beaver has a habit, when he smells the bark stone of another beaver, of covering it with leaves and twigs and then voiding his own bark stone or scent upon it. Doing this, he would be more likely to cover the trap than to be caught. What the object of this is, is of course unknown; but it is similar to the voiding of urine by dogs, foxes, and wolves in spots already used by another animal for the same purpose. 
But the beavers will take any fresh root or sapling for bait. The muskrat will take carrots, potatoes, apples, or any similar food. All of the weasel tribe-the mink, sable, fisher, skunk, ordinary weasel, etc., will take fish, fresh or salt. When using the latter, it should be toasted, so as to emit more smell. Old hunters, to get a good "fish smell," cut up any small fish, put the pieces into a bottle, and let it be in as warm a place as convenient for several days. As it decays the fish-oil rises, and this oil they put on any bait they happen to have. All of the weasel tribe, as well as foxes and wolves, are fond of any kind of fowl. The heads and legs and any other waste parts of both wild and domestic fowl are the best of bait. Even feathers scattered around the trap make the thing more attractive and real. A little musk mixed with assafœida, or mixed like the bark stone, or even a muskrat-skin, fixed so as to drag along the ground toward a trap, will make most of this tribe, as well as the fisher, follow it up to the trail. A strong piece of codfish will do the same. Some old hunters just keep one of these trail-bags tied by a string to their belt, and let it drag as they go from trap to trap. This multiplies their chances of having something in them next morning. Another secret of old hunters is to take the parts peculiar to the sex of the female wolf, fox, or dog, and proserve it in alcohol or whiskey for use. A small piece of this is used in drawing either fox or wolt to traps, and proves irresistible to the male; and no matter from which species it is taken, it proves alike attractive to either fox or wolf. It is not used as a bait, that is as food, but as the trail or drag is to bring the animal toward the trap. The trap may be baited as usual, or this substance may be suspended over the trap; in trying to reach it to smell at it, the animal steps into the trap. Foxes, wolves, and all the weasel tribe will take flesh and fish of any kind, with this exception-foxes, wolves, and dogs will not ent their own kind; weasels of every lind will. Toasted cheese forms a strong allurement for a fox. The bear will go anywhere for honey, and it is usual to smear this over a piece of pork or beef, or even upon an ear of corn, or just to smear it on the tre or stump near where the trap is set. The skunk considers mice a dainty; and raccoons will travel far for frogs, fish (broiled), salt or fresh; but an ear of corn is not disdained by him. Squirrels take Indian corn, nuts, etc. Woodchucks will take roots, corn, and bread. Wildeats take flesh or fish of any kind. In the northwest they are also taken with the baris stone bait previously described. In arranging traps for small bircis hemp-seed will be found more attractive than any other. Buckwheat is perhaps mora attractive for quails than any other grain. The par- 
tridge-also called pheasant in some places-may be caught with an apple once in a hundred years. We think even that unlikely. Otters, also, can be caught with the various grains-the small grains being best.

T'o Skin and Stuff animals is to suspend the body by a hook, so that both hands are at liberty. For small kinds a common fishhook will answer, with the barb broken off; and a cord attached a foot or two in length. This may be inserted among the bones near the tail after the skiu has been partly detached. Other implements required are the following: 1. A sharp lnife of almost any shape, but a surgeon's scalpel without a jointed handle is the best for small kinds, and the common butcherknife, which is of similar shape, for larger ones. 2. A strong, sharp pointed scissors, and for large skins, a shears is often useful. 3. Triangular glovers' needles, for sewing up skins; two or three sizes. 4. A pair of spring forceps, such as are used by surgeons, though not essential, are very useful. 5. A tape measure, three to six feet long. 6. A fine saw, or coarse flat file, to notch small bones. before brealing them, so as to break them evenly. Some use sharp edged nippers for this purpose. Large bones may be broken roughly, and the ends smoothed off. When a bird is shot, all large holes must be plugged with cotton or paper, and this also inserted in the mouth and throat, so as to prevent the flow of blood or other fluids. Blood on the feathers may be absorbed by sprinkling with plaster of Paris, ashes, dust, or sand, shaking off all that does not stick; then make a cone of paper, large enough to put the bird in, head down, and twist up the other end over it, taking care not to injure the tail feathers. This will secure smoothness of the feathers when the body stiffens. In cool weather it is best to postpone skinning for twelve to twenty -four hours, in order to allow the blood to coagulate, so that it will not flow so freely, and the fat hardening, also gives less trouble. Some use a ring of paper pinned round the body to obtain its exact girth, so that it can be stuffed out to the same dimensions afterward.

Before skinning, put fresh plugs in the mouth, nostrils, and large shot holes. Take the measurements and notes required; then make an incision from the breast bone down to the tail, not so deep as to open the intestinal cavity, and carefully separate the skin on each side, plugging or sewing up any holes accidentally cut too deep. If blood or fluid run too freely, absorb them by some dry ashes, plaster, or paper, and use these so as to protect the feathers; if necessary; keeping the fingers well powdered. Seperating the skin from one side. 
the leg is soon reached; this must be drawn out by the knee-joint as far as it can be, and the tendons cut where they go toward the foot. Break off the bone within the skin, and, having freed that leg, treat the other in the same way. It is most convenient in small birds to break these bones, and also those of the upper wing-joint, before beginning to skin, thus having the limbs less in the way.

After the legs are freed, cut down to the tail, and separate the body, leaving some of the vertebræ attached to support the feathers. Remove the oil-glands above the tail carefully from the skin, then insert the hook in the body, and hang it up, head downward. The skiri is then easily peeled off until the wings are reached, when it must be drawn to one side until the broken end of the shoulder-bones are reached, which may be slipped throngh the muscles, and pulled out as far as possible. The muscles must then be cut off, and this wing being freed, the same process is used for the other.

The skin then slips off easily as far as the head, and, if large, must be supported, so that its weight may not stretch the ne $\theta^{-7}$. In drawing it over the head, be careful not to tear it, and use the finger-nails more than the knife. The ear membraues are easily drawn out with it, and on reaching the eyes, the attachment of the lids must be carefully separated from the eye-ball, so as to injure neither the lids nor the eye-ball, as the fluids escaping give trouble. Then cut off the back part of the skull, remove the brains and the eyes, clear away all remains of muscle, etc., from the skull, and sprinkle or smear the skin with arsenic. Fill the eye-sockets and other cavities around the head with cotton, or other stuffing, and draw the skin back to its orginal shape. If the neck has dried during the operation, it will need moistening before retraction.

The second joints of the wings now require cleaning from the muscles, etc. This may be done in small birds by carefully drawing the skin down over the bones, loosening it with the finger-nails. Large birds, however, need an incision under the wing, reaching the whole length of the joint, which may be sewed up afterward by a few stitches. Arsenic ointment must be applied freely to all these parts. The wing-bones must now be connected by a string passed through the space between the bones, or a thread sewed through the ligaments, so that it can not slip. Do not draw the wings too close together, but leave as nearly the natural distance between them as is practicable. Cotton or tow may be now wound round the broken ends of the wing and leg bones, a roll of it inserted in the neck, and enough put in the body to fill it out to its natural shape. 
When the legs are tied together, no stitches are generally necessary to sew up the cut. If there are large holes in the skin, they should be sewed up from the inside before putting in the stuffing. In large birds it is well to sew on wide strips of rag along the inner edges of the cut made in the slin to protect the feathers during the operation of slinning, removing the rags afterward. Very badly soiled skin can, however, be cleaned by the taxidermist; and, provided thy have not lost any feathers, are still useful. . The bill should generally be tied shut by a string passed through the nostrils, and the label may be put there, or on the legs. Very long necks are best stuffed by rolling up a long cylinder of paper, and passing it down the throat or from the inside. The neck may then be bent down along the side of the body, and the legs bent up so as to make as compact a specimen as possible. Having smoothed down the feathers, the bird must now be pushed carefully inside a cylinder of stiff paper of the proper size, and laid on its back to dry. Hanging it up by the bill or feet stretches it too much. If carefully dried, it retains a good shape, and may be freely handled afterwards.

Some birds, especially ducks and woodpeckers, have the neck so slender that the head can not be drawn through it by skinning in the usual manner. In these an incision must be made on the most injured side, from the ear domn far enough to allow the head to be cleaned through it. The body may then be skinned as usual, or the incision may be continued down the neck to the bare space under the wing, and the skin taken off without cutting it elsewhere. To sew this up requires care in order to adjust the feathers nicely, and the stiches must be taiken from within outward. Some persons skin all birds in this manner; but the feathers are more apt to fall out of those birds that have them loosely attached.

There is much diff rence in the ease with which a bird may be skinned, according to the relative toughness of skin, and adhesion of feathers. A liumming-bird is more easily skmmed than a pigeon, and those of the size of a robin take much less time than an eagle. For practice, the best are blackbirds and jays, those not too fat being preferable.

English Secrets of Fired Catehing.- "Jingling for Robbius" is a slmple art, but it is founded upon close observation of nature. The jingler provides himself with a tame robin caged; a piece of timber about a foot square, to which is attached a net, which flies over it at the proper moment by means of a spring; and two penny pieces. He selects a rural spot, deposits the cage on the board at the foot of a tree, retreats to a little distance, and then balancing the pennies, one on each forefinger, chinks them together. Now, if there is such a thing as a cock- 
robin in the vicinity, he immediately exposes himself. Birds, like men, have their weaknesses, and jealousy and inquisitiveness are the especial weaknesses of cock. robins. "Chink, chink," is the call note of the male bird to his mate; and an unwouted "chink" effects him to that degree, that he is almost thrown off his perch. His ever bright, round eyes, grow rounder and brighter, with all the keenuess of curiosity and the greenness of green-eyed jealousy. "Chink, chink," go the pence. The deluded bird sets his head awry; and he says in his heart, "What does this mean, I should like to know," "Chink, chiuk! Chink, chink!" he can stand it no longer. His quick vision has detected the bird in the cage, and he sweeps down to ciemand an explanation of the strauger's intentions, and may be to require immediate satisfaction. But, alas! no sooner does the vietim of his own passions alight on the board, than the spring that hitherto withheld the net is released, and encloses both the caged bird and the wild one.

"Trolling for larks" at night. Selecting a meadow which larks are known to frequent, the snarers provide themselves with a long net. This is loaded all down one side with stones or leaden weights, to keep it close to the ground. Stretching the net out to its fullest extent, two men take a corner of the side that is not weighted, and slowly drag the field, until the fluttering and screaning of the poor little prisoners tell them they lave had a good haul. All in the dark the men go on their knees, and thrusting their luands through the meshes, make their captures, which they slip into store cages. These are long wooden cages, with a round hole cut in the top, to which is fastened the leg of a stocking, which hangs loosely inside, thus making it an easy affair to drop the larks, and an impossible one for them to get ont again. It generally happens that as many larks are taken dead as alive by this system. Indeed it is almost impossible to take them at all, except with the assistance of two horses. This is explained by the fact that the sense of hearing is very acute in the lark-the slightest noise, ii it be of an unusual character, alarming them. Now larks are used to the tramping of cattle, but not to the footsteps of men; sometimes, therefore, the snarers take each one of the dragging ropes in their hand, and lead a horse by the bridle with the other; the birds are undisturbed by the tramping of the four footed creature, and the bipeds, keeping step with the horses, are not detected.

The metropolitan bird-catcher is not content with larks-he must have nightingales also; but none but the most enthusiastic bird-catchers are addicted to this branch of the business, which is called "lying out." For, in the first place, it is almost without excitement; and in the next, although the birds, when caught in prime singing condition, fetch a high price, the difficulty in catching them is so great as to make the trade unprofitable. This is how it is practiced. A trap exactly similar to the robin trap is used, only instead of a tame bird in a cage, a hook is chriven in the centre of the board, and on the hook is impaled a lively worm. The first thing is to discover a bush frequented by a nightingale. You must watch him into the bush, allow him to pass the night there, and see him well off in the morning before you set your trap. Then you dig the ground up within a few yards of the bush and bury the trap so that only the writhing worm in the midale of the net attached is visible: the net being as much the color of fresh earth as possible. Then you must retire and tateh for the chance of the bird spying out the worm when ho hops down to lonk for food in the morning. If the worm happens to be still alive. and its wriggling attracts the attention of the nightingale, then you have a chance of catching him; if not, you must wait 1.util this lucky collusion of circumstances does occur.

"Pcgging for chaffinches" is by far the most curious and interesting of all the branch $e s$ of the $b$ rd-catching art. Before you think of going pegging, you must get a thorough good pegging chaffinch. These birds are trained to the busincss. 
As soon as the new year's bird gives sign of coming into song (which you will know by the beak turning blue), you must put the cage in a stout black bag, and hang him up in his usual place. He will perhaps-sulk a little at first; if so, he will require a little encouragement. It is astonishing what odd noises will bring him out-the rasping of a tobacco pipe on the back of a knife, the frying of beef steaks, or scraping a bow on a fiadle. In a little time he will pipe away as well in the black bag as he would out of it. Then, by degrees you must use him to being handled. Stand his cage on the table at your elbow, carry him about the loouse, or in the garden, and if he will stand all this, and sing as he goes, you may venture a pegging trip with him.

Besides the decoy bird, you will require a stuffed chaffinch-or "stall "-looking as much like life as possible. Then you must have half a dozen pegs. These are made of whalebone, and must be eight inches long, and about as thick as an ordinary meat-skewer, fixed with the pointed half of a stout needle in one end.

Then you want some bird-lime, and good bird-lime it must be, or all your other preparations are of no avail. It should be so plastic that a piece the size of a small pea may be drawn out in a thread half a yard long.

A bright, warm May morning is the best time; and, supposing you have everything in perfect order-the pegs, the stall, the lime in a little tin box, and your decoy in his cage, tied in a handkerchief of the most unobtrusive color-you start off. When you get amoug the trees, you will hear presently perhaps one, perhaps two, chaffinches piping away over your head. Now to business. Mark the tree that contains the stoutest singer, take out your pegs and lime, fasten the stuffed bird securely to one of the pegs, and then smear austher peg all over with bird lime. Stick the perch on which is standing the stuffed bird firmly into a tree adjoining the one containing the wild songster ; aud, about six inches above the "stall," drive the limed peg. Place the decoy (still in the handkerchief) at the foot of the tree. If he is a good bird, the singing of the wild chafinch will stimnlate to the utmost his exertions to drown the voice of the other; if he is a coward, the wild fellow is the conqueror, and the trained decoy will whine and chirrup pitifully. However, supposing him to be "a good brazen bird," the wild chaffinch will gradually work himself into a rage, and fluttering here' and there-sereaming out his motes in defiance-to find the intruder. Presently his eye catches the stuffed bird on the peg; and has not the least doubt but that he has discovered the delinquent; with an angry cry, down he swoops sheer on to the stuffed bird's back; the sticky peg just abuve catches his pinions, and either he hangs there, or he brings the peg down with him, and runs sereaming along the gromnd till you overtake him. 
Preserving and Manufacturing Secrets.-This book gives plain drections for preserving, canning, and storing all kinds of fruits and vegetables, and for manufacturing all kinds of foreign and domestic liquors, home-made wines and summer beverages. It gives a new, simple and cheap plan of preserviug eggs fresh for five years (if necessary), so that when opened they wiil taste as if ireshly laid. This receipt alone bas often been sold for $\$ 5$. It tells housekeepers how to make all varieties of palatable and delicious fruit jellies and jams. It shows how to make a fruity and sweet tasting cider without apples that when bottled will foim and effervesce like genuine champagne. It tells how to keep fruit and vegetables tresh all the year round. All about pickling. How to make all kinds of liquors at home at a trifling expense, and which cannot be told from that sold at \$5 to \$10 a gallon, etc., etc. Mailed for only 50 cents.

Secrets for Farmers.--This book tells how to restore rancid butter to its original flavor and purity; a new way of coloring butter; how largely to increase the milk of cows; a sure cure for kicking cows; how to make Thorley's celebrated condimental food for cattle; how to make hens lay every day in the year; it gives an effectual remedy for the Canada thistle; to save mice girded trees; a certain plin to destroy the curculo and peach borer; how to convert dead animals and bones into manure; Barnet's certain preventive for the potato rot, worth $\$ 50$ to any farmer; remedy for smut in wheat ; to cure blight in fruit-trees; to destroy the potato bug; to prevent mildew and rust in wheat; to destroy the cut worm: home-made stump machine, as good as any sold; to keep cellars from freezing, etc., etc. It is impossible to give the full contents of this very valuable book here, space will not allow. It will be mailed for 30 cents.

The Housewife's Treasure.-A manual of information of everything that relates to household economies. It gives the methol of making Jackson's Universal Washing Compound, which will clean the dirtiest cotton, linen or woolen cloths in twent5 minutes without rubbing or harming the material. This receipt is being constantly peddled through the country at $\$ 5$ eech, and is certainly worth it. It also tells all about soap-making at home, so as to make it cost about one-quarter of what bar-soup costs ; it tells how to make candles by moulding or dipping; it gives seven methods for destroying rats and mice; how to make healthy bread without flour (something entirely new); to preserve clothes and furs from motbs; a sure plan of destroying house flies, cockroaches, beetles, ants, bedbugs and fleas; all about house-cleaning, papering, etc., etc., and hundreds of other valuable bints just such as housekeepers are wanting to know. Mailed for 30 cents.

Fducating the Horse.-A new and improved system of educating the horse. Also a treatise on shoeing, with new and valuable receipts for diseases of horses, together with the Rules of the Union Course. This book contains matter not to be found in auy other work on the horse. Mailed for 25 cents.

Our Boys' and Girls' Favorite Speaker.-Containing patriotic, Sentimentul, Poetical, and Comic Gems of Oratory, by Chapin, Dickens, Dow, Jr., Beecher, Burns, Artemus Ward, Everett, "Tennyson, Webster, and others. Mailed for 20 cents.

The Common-Sense Cook-Book.-Showing fully what to eat and how to cook it. Mailed for 20 cents.

Address FRANK TR. TRED,

139 Eighth Street, New York. 
Art of Ventriloquism.-Contains simple and full directions by which any one may acquire this amusing art, with numerous examples for practice. Also instructions for making the magic whistle, for imitating birds, animals, and peculiar sounds of various kinds. Any boy who wishes to obtain an art by which he can develop a wonderful amount of astonishment, mystery, and fun, should learn Ventriloquism, as he easily can by following the simple secret given in this book. Màiled for 15 cents.

Magic Trick Cards.-Used by Magicians for performing Wonderful Tricks. Every boy a magician! Every man a conjurer! Every girl a witch! Every one astonished! They are the most superior Trick Cards ever offered for sale, and with them you can perform some of the most remarkable illusions ever discovered. Maired, with full direetions, for 25 cents a pack.

The Black Art Fully Exposed and Iaid Bare.-This book contains some of the most marvellous things in ancient and modern magic, jugglery, etc., ever printed, and has to be seen to te fully appreciated. Suffice it to say that any boy knowing the secrets it contains will be able to do things that will astouish all. Illustrated. Mailed for 25 cents.

Swimming and Skating.-A complete Guide for learners. Every reader should possess this book so as to learn how to swim. Many a young life has been nipped in the bud, many a home made desolate for the want of knowing how to swim. Very fully illustrated. Mailed for Twenty cents.

Singing Made Easy.-Explaining the pure Italian method of producing and cultivating the Voice, the Management of the Breath, the best way of Improving the Ear, and much raluable information, equally useful to professional singers and amateurs. Mailed for 20 cents.

The Amateur's Guide to Magic and Mystery.-An entirely new work, containing full and ample instructions on the Mysteries of Magic, Sleight-of-Hand Trieks, Card 'I ricks, ete The best work on Conjuring for Amateurs published: Iliustrateả. Mailed for 25 cents.

The American Sphinx.-A choice, curious and complete collection of Anagrams, Enigmas, Charades, Rebuses, Problems, Puzzles (ryptographs, Riddles, Conundrums, Decapitations, Word Changes, etc., etc. Profusely Illustrated. Mailed for 25 cents.

Life in the Back Woods.-A Guide to the Successful Hunting and Trapping of all kinds of Animals. This is at once the most complete and practical book now in the market. Muiled for 20 cents.

The Happy Home Songster.-A casket of time-honored vocal gems. Only favorite and world-wide known songs are admitted in this and following book. Mailed for 20 cents.

The Fireside Songster.-A collection of the best-known sentimental, humorous and comic songs. Mailed for 20 cents.

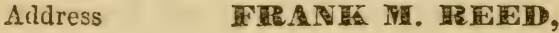

139 Eighth Street, Fev York. 


\section{Good Books Mailed on Receipt of Price.}

Love and Courtship Cards,-Sparking, Courting, and LoveMaking all made easy by the use of these Cards. They are arranged with such apt conversation that you will be able to ask the momentous question in such a delicate manner that the girl will not suspect what you are at. They may be used by two persons only, or they will make lots of fun for an evening party of young people. There are sixty cards in all, and each answer will respond differently to every one of the questions. Mailed for 30 cents.

How to Woo and How to Win.-This interesting work contains full and explicit rules for the Etiquette of C'ourtship, with directions showing Horr to Win the Favor of the Ladies; How to begin and end a Courtship; and How Love-Letters should be written. It not only tells how to win the favor of the ladies, but how to address a lady; conduct a courtship; "pop the question"; write love-letters; all about the rnarriage ceremony ; bridal chamber; after marriage, etc. IIailed for 15 cents.

Leisure-Hour Work for Ladies.-Containing Instructions for Flower and Shell Work; Antigue, Grecian, and Theorem Painting; Botanical Specimens: Cone Work; Anglo-Japanese Work; Decalcomanie; Diapkame; Leather Work ; Modelling in Clay; Transferring; Crayon Drawing; Photograph Coloring, etc., etc. A very complete book, and one that no soung lady laving spare time can afford to be without. Diailed for 20 cents.

The Dancer's Guide and Ball-Room Companion.-Including Etiquette of the Ball-Room. This is one of the best and most complete books crer published, and it contains all that is required to know, by the most plain or fashionable, of ball-room etiquette, behavior, manners, etc., besides cuntaining full and minute directions for all of the popular and fashionable dances, with ample explanations, calls, etc. Mrailed for 25 cents.

The Magic Dial.-A perfectly new invention, by the use of which secret correspondence may be carried on without the fear of detection. It is simple, reliable, and can be used by any person. By its use the postal card is made as private as a sealed letter. It is just the thing for lovers. Mailed for 25 cen/s, or two for 40 cents.

How to Fintertain a Social Party.-A Collection of Tableatix, Games, Amusing Experiments, Diversions. Card Tricks, Parlor Mragic, Philosoplical Recreations, etc. Profusely Illustrated. This book contains chaste and enjoyable amusement and entertainment enough for a whole winter. Mailed for 25 cents.

Shadow Pantomime of Mother Goose.-A miniature theatre for the children, with stage, scenery, figures, and everythiug complete, to perform the laughable Shadow Pantomime of Mother Goose. A book of explanations, with 14 engravings, accompanies it. Mailed for 30 cents.

How to Write Short-Hand.-By the aid of this book any person of the most ordinary intelligence may learn to write short-hand, and report sermons, lectures, speeches, etc. Mailed for 25 cents.

Fvery Lady Her Own Dressmaker.-A new book on Dressmaking, Bleaching, Ironing, Renovating, Dyeing, etc., etc. Mailed for 20 cents.

Adriress FEA

139 Eighth Street, Nev York. 


\section{Good Books Nailed on Receipt of Price.}

Courtship and Marriage; or, The Mysteries of Making Love fully Explained.-This is an entirely new work on : most interesting subject. Contunts.-First steps in courtship; Advice to both parties at the outset; Introduction to the lad $\bar{y}^{3} \mathrm{~s}$ lamily; Restrictions imposed by etiquette: What the lady should observe in early courtship; What the suitor should observe: Etiquette as to presents; The proposal; Mode of refusal when not approved; Conduct to be observed by a rejected suitor; Refusal by the lady's parents or guardians; Etiquette of an engagement; Demeanor of the betrothed pair; Should a courtship be long or short; Preliminary etiquette of a wedding; Fixing the das; How to bo married; The trosseau; Duties to be attended to by the bridegroom; 'Who should be asked to the wedding; Uuties of the bridesmaids and bridegroomsmen; Etiquette of a wedding; Costume of briale, bridesmaids, and bridegroom: Arrival at the church; The nuarriage ceremonial; Registry of the marriage; Return home, and wedling breakfast; Departure for the honeymoon; Wedding cards: Modern practice of "No Cards;" Reception and return of wedding visits ; Practical advice to a newly married couple: Mailed for 15 cents.

How to Behave.-A Hand-Bonk of Etiquette and Guide to True Politeness. - CoNTENTs.-Etiquette and its uses ; Introductions : Cutting acquaintances; Letters of introduction; Street etiquette; Domestic etiquette and duties ; Visiting; Receiving company; Evening parties; The lady's toilet; The gentleman's toilet; Invitations; Etiquette of the ball-room; General rules of conversation; Bashfulness, and how to overcome it; Dinner parties; Table etiquette; Carving; Servants; 'Travelling: Visiting cards; Letter-writing; Conclusion. This is the best book of the kind yet published, and every person wishing to be considered well-bred, who wishes to understand the customs of good society, and to avoid incorreet and vulgar habits, should send for a copy. Mailed for 15 cents.

The Model Letter-Writer.-A Comprehensive and Complete Guide and Assistant for those who desire to carry on epistolary correspondencecontaining instructions for writing Letters of Introduction; Letters on Business; Letters of Recommendation; Applications for Employment; Letters of Congratulation; Letters of Condolence; Letters of Friendship and Relationship; Lovo Letters; Notes of Invitation; Letters of Favor, of Advice, and of Eucuse, etc.s etc., together with appropriate Answers to each. This is an invaluable book for those persons who have not had sufficient practice to enable them to write letters without great effort. Mailed for 15 cents.

The Complete Fortune-Teller and Dream Book.-This book contains a complete Dictionary of Dreams, alphabetically arranged, with a clear interpretation of each dream, and the lucky numbers that belong to it. It includes Palmistry, or telling fortunes by the lines of the band; fortune-telling by the grounds in a tea or coffee cup; how to read your future life by the white of an egg; tells how to know who your future husband will be, and how soon you will be married; fortune-telling by cards ; Hymen's lottery ; good and bad omens, etc., etc. Mailed for 15 cents.

The Lover's Companion.-A book no lover should be without. It gives Handkerchief, Parasol, Glove and Fan Flirtations; also, Window and Dining-table Signalling; The Language of Flowers; How to lisiss deliciously; Love Letters, and how to write them, with specimens; Bashfulness and Timidity, and how to overcome them, etc., etc. Mailed for 25 cents. 

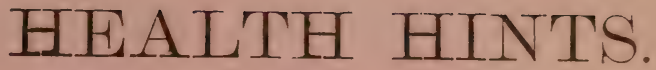

A new book showing how to Acquire and Retain Bodily Symmetry, Health, Vigor, and Beauty. Its contents are as follows: Laws of Beauty-Air, Sunshine, Water, and Food-Work and Rest-Dress and Ornament-The Hair and its ManagementSkin and Complexion - the Mouth-The Eyes, Ears and Nose-The Neck, Hands, and Feet-Growth and Marks that are Enemies of Beauty-Cosmeties and Perfumery.

Fat People. - It gives ample rules how Corpulency may be Cured-the Fat made Lean, Comely and Active:

Iean People.-It also gives directions, the following of which will enable Lean, Angular, Bony or Sharp Visaged People, to be Plump and Rosy Skinned.

Gray Hair.-It tells how Gray Hair may be Restored to its natúrul color without the aid of Dyes, Restorers, or Pomades.

Balduess. - It gives ample directions for Restoring Hair on Bald Heads, as well as how to stop Falling of the Hair, how to Curl the Hair, etc.

Beard amd Mustache.-It tells what Young Men shouid do to acyuire a Fine Silky and Handsome Beard and Mustache.

Freckles and Pimples.-It gives full directions for the Cure of Sunburn, Freckles, Pimples, Wrinkles, Warts, etc., so that they can be entirely removed.

Cosmetics.-This chapter, among other things, gives an Analysis of Perry's Moth and Freckle Lotion, Balm of White Lilies, Hagan's Magnolia Balm, Laird's Bloom of Youth, Fhalon's Enamel, Clark's Restorative for the Hair, Chevalier's Life for the Hair, Ayer's Hair Vigor, Professor Wood's Hair Restorative, Hair Restorer America, Gray's Hair Restorative, Phalon's Vitalia, Ring's Vegetable Ambrosia, Mirs. Allen's World's Hair Restorer, Hall's Tegetable Sicilian Hair Renewer, Mtartha Washington Hair Restorative, etc., etc. (no room for more), showing how the lead, etc., in these mixtures cause disease and oftentimes premature death. Mailed for 50 cents.

\section{'He Management and Care of Infants and Children.-By} Geo. Combe, M.D. This is the best book ever written on the subject, and is one that no mother of a family can afford to be without Its usual price in the book stores is $\$ 1.50$, but it will be mailed-the latest and most complete edition-for only 75 cents.

\section{Address $\quad$ FIRANI TH. REED,}




\section{OLD SECRETS AND NEW DISCOVERIES:}

\section{Containing Information of Rare Value for All Classes, in all Conditions of Society.}

It tells all about Electrical Psychology, showing how you can biologize any person, and while under the influence he will do anything you may wish him, no matter how ridiculous it may bc, and he cannot help doing it; also, how to mesmerize-a secret that has been sold over and over again for $\$ 10$; how to make a person at a distance think of you, and how to charm those you meet and make them love you, whether they. will or not.

It tells how to make the wonderful Magic or Invisible Photographs and Spirit Pictures; the Eggs of Pharo's Serpents, which when lighted, though but the size of a pea, there issues from it a coiling serpent; how to perform the Davenport Brothers' "Spirit Mysteries"; how to copy any kind of drawing or picture, and more wonderful still, to print pictures from the print itself; how to make gold and silver from block-tin (the least said about which, the better); also, how to take impressions from coins, and how to imitate gold and silver.

It tells how to make a horse appear as though he was badly foundered; to make a horse temporarily lame; how to make him stand by his food and not eat it; how to cure a horse from the crib or sucking wind; how to put a young countenance on the horse; how to cover up the heaves; how to make him appear as if he haa the glanders; how to make a true-pulling horse baulk; how to nerve a horse that is lame, etc., etc. These horse secrets are being continually sold at one dollar each.

It tells how to make a cheap Galvanic Battery; how to plate and gild without a battery ; how to make a candle burn all night; how to make a clock for 25 cents; how to detect counterfeit money; how to bavish and prevent mosquitoes from biting; how to make yellow butter in winter; Circassian curling fluid; Sympathetic or Secret Writing Ink; Cologne Water; Artifioial honey; Stammering; how to make large noses small; to cure drunkenness : to copy letters without a press ; to obtain fresh blown flowers in winter: to make a good burning candle from lard; and scores of other wonderful things for which there is no room to mention. "Old

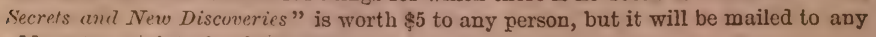
address on receipt of only 50 cents.

Address

FIRANIR IT. IREED,

139 Eighth Street, New York. $3477-265$ 



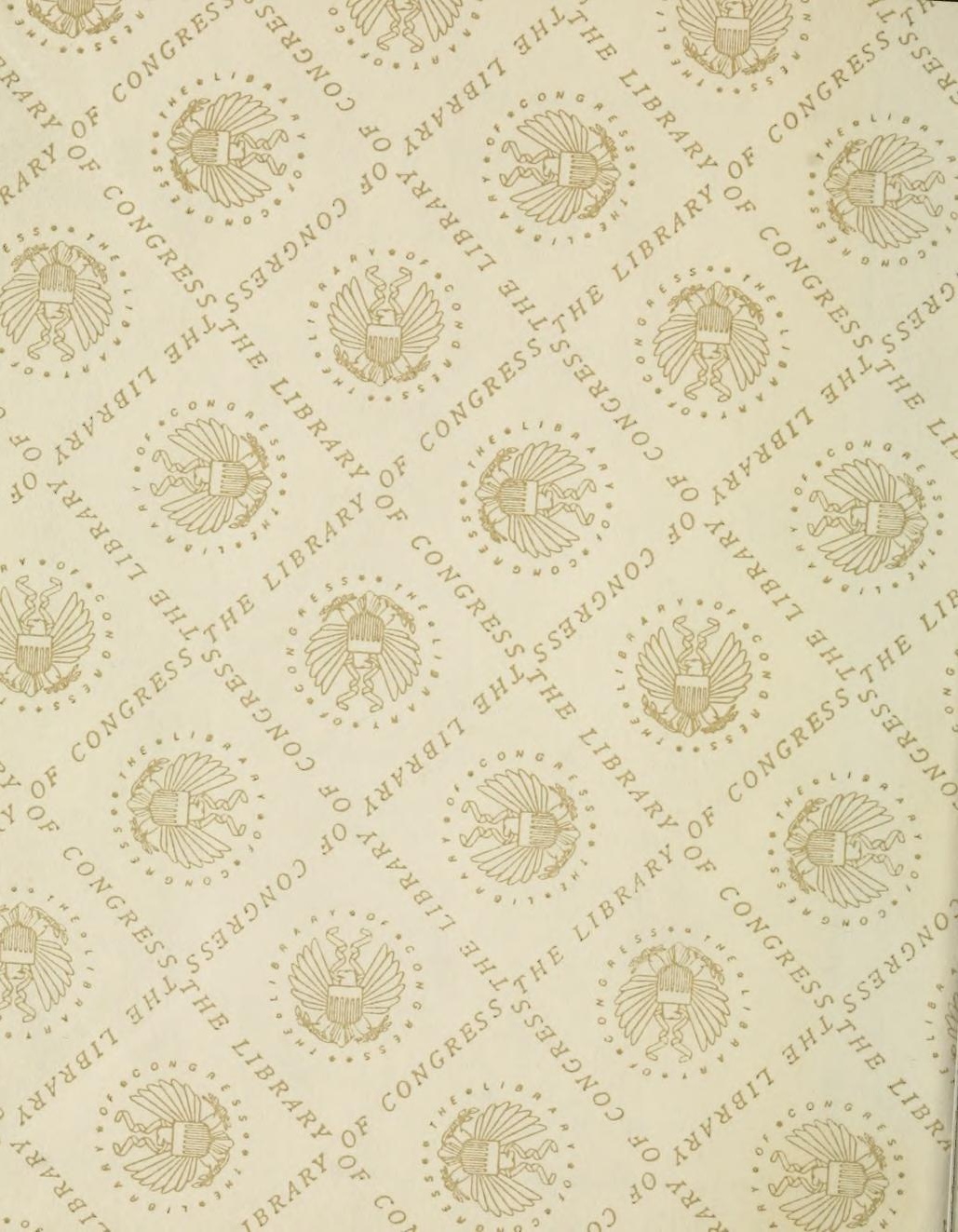





\section{LIBRARY OF CONGRESS}

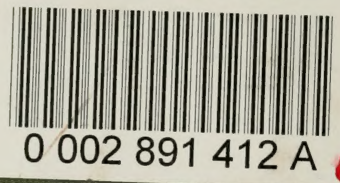

